\title{
Inflection Point of Green Total Factor Productivity by Low-Carbon Regulation from Chinese Economics Recovery
}

\author{
Youqiang Ding (i) and Yufeng $\mathrm{Hu} *$ (1) \\ School of Finance, Tongling University, Tongling 244061, China; dingyouqiang@163.com \\ * Correspondence: huyufenghzu@163.com
}

Citation: Ding, Y.; Hu, Y. Inflection Point of Green Total Factor

Productivity by Low-Carbon

Regulation from Chinese Economics Recovery. Sustainability 2021, 13, 12382. https://doi.org/10.3390/ su132212382

Academic Editors: Donato Morea and Attila Bai

Received: 12 August 2021

Accepted: 5 November 2021

Published: 9 November 2021

Publisher's Note: MDPI stays neutral with regard to jurisdictional claims in published maps and institutional affiliations.

Copyright: (C) 2021 by the authors Licensee MDPI, Basel, Switzerland. This article is an open access article distributed under the terms and conditions of the Creative Commons Attribution (CC BY) license (https:// creativecommons.org/licenses/by/ $4.0 /)$.

\begin{abstract}
The sustainable growth path of emerging economies has transformed from the traditional extensive model to high-quality development. Due to the impulse force of low-carbon regulation, the measurement of input-output efficiency changed into green total factor productivity (GTFP) which considers environmental factors. Past research on GTFP focused on enterprise investments to promote green innovation for their resource allocation efficiency, but green investments are often limited from marketization that is interactively influenced by low-carbon regulation. Therefore, handing green investment to mitigate carbon dioxide emissions for green economics recovery is a big challenge. Then these hypotheses are tested by the main study of 170 cities in China. Results suggested that GTFP has an inverted S-shaped curve with three inflection points and four development stages under the influence of low-carbon regulation. It means that improving green productivity is costly toward making green investments without the driving of green innovation. However, the inflection point of the growth curve-when enterprise investment activities ignore the interaction between low-carbon regulation and green investment policy-will come slowly to a period of high-quality development. Moderating results suggested that the green productivity would be weakened and the inflection point would be delayed by the low-carbon marketization index if the low-carbon regulation intensity was neglected. Therefore, this research advanced an effectively co-ordinate growth curve to search for the inflection point of green economics recovery.
\end{abstract}

Keywords: low-carbon regulation intensity; low-carbon marketization index; green innovation; green investment; green total factor productivity

\section{Introduction}

Many countries advocating for green development have made great efforts on the improvement of GTFP. It is a sensitive factor adding environmental input-output efficiency for the strategic direction of enterprises to encourage their green innovation willingness to reduce the carbon dioxide emission in order to match carbon mitigation targets. Generally speaking, the carbon mitigation behavior is impacted by the effects of low-carbon regulation, such as tax for the high-carbon companies and incentives to the projects that aim to mitigate carbon emission [1]. Scholars have long recognized that the effects of low-carbon regulation on GTFP are characterized in a multi-stage process, including positive U-shaped, inverted U-shaped, and N-shaped curves [2-4], but this process of green performance starts from initial economic growth and decreases due to the shock of low-carbon regulation, then finally shifts into an inflection point through green innovation $[5,6]$. Thus, the positive U-shaped or the inverted U-shaped is just one part of the growth curve of GTFP, and the $\mathrm{N}$-shaped also does not fully reveal the inflection points [7]. That is to say, each of them ignores the whole characteristics of the growth curve. It is very useful for a new curve of GTFP to match the theory and explain the resilience change of enterprise performance.

Theoretically, it is believed that enterprise performance will be declined if the government mitigates carbon dioxide emissions by environmental regulation instruments [8]. However, the Porter Hypothesis challenged this theory and argued that there would be 
an inflection point, meaning that enterprises gain a competitive advantage to mitigate the decline to improve the resilience of enterprise performance by green innovation [9-12]. Based on this, present scholars are drawing the relevant graphics research about the growth curve and the inflection points of GTFP. Especially in the post-epidemic era, the green economic recovery provided new opportunities for green development [13], and the transformation of green technology achievements is used to improve the green investment quality by building a market-oriented innovative system of green technology and capital elements. However, the enterprise transformation of low-carbon management may be subjected to a severe test [14]. Thus, the low-carbon regulation should search for a coordinated development path of green transformation and economic rehabilitation to create an orderly competitive environment and strengthen enterprise capabilities for green economics recovery $[4,15]$.

Although past research considered green innovation and low-carbon regulation as the main factors of the allocation efficiency of green elements, little research has focused on the integration impact between green technology and capital elements, and even less research has fully explained the growth curve of GTFP. This paper wanted to describe the GTFP changes under the influence of low-carbon regulation, enrich the research of low-carbon regulation, and provide guidance for the government and enterprises. Therefore, we tried to research the effects of low-carbon regulation by the transcendental logarithmic production function model to analyze the mechanism of green innovation on GTFP under the mediating role of green investment. The main contributions are as follows: 1 . The combination methods of theoretical and empirical are used to study the relationship between low-carbon regulation and GTFP. 2. Two variables of green innovation and green investment are introduced to explain the impact path of low-carbon regulation on GTFP. 3. We found a meaningful conclusion that the growth curve of GTFP is inverted S-shaped.

\section{Literature Review and Research Hypothesis}

\subsection{Green Innovation and Green Total Factor Productivity}

Green innovation has inherited the theoretical innovation paradigm by Joseph Schumpeter to be described as an enterprise transformation of technologies, processes, or products to reduce environmental pollution and energy consumption [16]. It is becoming an endogenous driving force for GTFP growth [17]. In the present research, it has been proven that green innovation is an important power for enterprises to change into green growth with the dynamic evolutionary game between factor-resource allocation and social-economic development. Especially after the strengthening role of low-carbon regulation, more enterprises try to change their carbon emission pattern from green innovation. That makes them choose a new path to the synergistic growth of economic and environmental performance [18].

However, the growth curve of GTFP will be different from the diversity of green innovation. Qian and Li [19] found that enterprise activities of green innovation have relatively higher performance in energy saving and consumption reduction, and the adjustment of the energy consumption structure is more conducive to improving the performance of carbon mitigation. Furthermore, some studies showed that the enforcement function of environmental regulation spurs enterprises to make green innovations to improve green productivity. According to Yuan and Chen [20], only strictly low-carbon regulation is helpful to improve the green innovation level. It has an indirectly positive U-shaped effect on the transformation of the manufacturing industry. In other words, green innovation has two effects on GTFP, not just a simple positive or a negative correlation. Thus, we propose the following hypothesis.

Hypothesis 1 (H1). Green innovation has a nonlinear effect on green total factor productivity. 


\subsection{Green Innovation and Green Investment}

The enterprise transformation of green technology achievements is mainly restricted by the factors such as capital, talent, and knowledge. These factors are significantly related to green investment. The empirical results of Lanjouw and Mody [21] show that there is a significant positive correlation between the investment in environmental protection and the number of green patents. In further research by Zhang and Wang [22], they found that the intensity of government environmental regulation not only improves the enterprise capability of green innovation but also has a positive effect on green investment.

Some scholars also believed that it needs certain conditions for the relationship between green innovation and green investment. For example, Pei et al. [23] found that, although private investment can promote technological innovation, there is not a significant relationship between green investment and technology innovation under the effect of environmental regulation because it is the prerequisite of a good investment environment for enterprises to implement green innovation, and enterprise investment will be guided by low-carbon regulation in the process of green innovation. Therefore, we propose the following hypothesis.

Hypothesis $\mathbf{2} \mathbf{( H 2 )}$. There is a positive correlation between green innovation and green investment.

\subsection{Mediating Role of Green Investment}

The previous study has shown that investment efficiency is a necessary condition for the optimal allocation of factor resources [4], but the most current green investments are inefficient. There are two main reasons for this: on the one hand, the management model of enterprise investments was used to ignore resource allocation efficiency, and the lowcarbon transformation of enterprise investment tends to remain at nongreen innovation, which caused many problems such as excessive redundancy. These problems usually make the pure technical efficiency and scale efficiency weak [4]; on the other hand, the enterprise capabilities of green investment not only have a positive effect on the efficiency of green technology but also have a negative effect on the scale efficiency of green performance. Generally speaking, the growth of green performance will lead to a gradual decline in green productivity [24].

Therefore, the green investment may cause a decrease in green productivity when enterprises focused solely on the benefits return. They should pay more attention to controlling environmental pollution if their willing wants to see a green productivity result. Only in this way can they reduce the undesired output and improve the environmental technological condition effectively. Thus, we propose the following hypothesis.

Hypothesis 3 (H3). Green investments have nonlinear effects on green total factor productivity.

Recent studies also have found that GTFP is influenced by the correlation between green technologies and green capitals. This result is in the form of two ways: on the one hand, the implementation of green innovation for enterprises inevitably consumes human, financial, material, information, and other factors. These implement activities require a large number of green funds, but most enterprises do not have sufficient funds to make a long time and uncertain result for green innovation. Research by Guo and Zhao [25] suggested that enterprises should take green investment and financial business as the main direction to optimize their green investment strategy. The green bank should be built as a public service platform to support green innovation and provide the necessary services for the transformation of green technology achievements; on the other hand, the impact of green investment on GTFP is characterized as periodic changes. Enterprises should enhance the research and development of green technologies if they want to plan and implement green investments. This will strengthen the investment effectiveness and improve the financial services [26]. Research by Liao et al. [27] shows that there is a 
significant positive correlation between green investment and green welfare. It means that the benefits will improve citizens' green welfare by government tax reduction or subsidy.

Therefore, green investment can promote the transformation of green technology achievements and the allocation efficiency of green elements. Thus, we propose the following hypothesis.

Hypothesis 4 (H4). Green investment plays a mediating role in the relationship between green innovation and green total factor productivity.

\subsection{Moderating Role of Low-Carbon Regulation Instruments}

Considering the integrated development of green technology and capital elements, the low-carbon regulation should have "two hands": The first one should push forward the market-oriented reform of green elements on improving the investment level. This is the term of low-carbon marketization index. The other one should focus on the lowcarbon regulation intensity to improve the environmental quality. This is the term of low-carbon regulation intensity. Under the combined effect of them, more enterprises increase investments to carry out independent innovation or introduce foreign technology to promote green innovation. They will improve the enterprise performance to foster GTFP growth $[28,29]$.

Due to the uncertainty of the external environment, the mechanism of low-carbon regulation is becoming more and more complex. It can promote the enterprise's green innovation level. The research of Berman and Bui [30] argued that the total factor productivity increased by the environmental regulation. However, it can also promote nongreen innovation to a certain extent [23]. As the research of Yuan and Xiang [31] argued, environmental regulation would restrict productivity growth. At the same time, the low-carbon regulation will be impacted by the market-originated interference, which makes the effect become a deviation between actual performance and desired objectives [32,33]. For example, the empirical evidence of $\mathrm{Li}$ [34] showed that low-carbon regulation has a strong effect on green process innovation and green product innovation because of the positive regulation of marketization. Therefore, the appropriate choice of low-carbon regulation intensity must dynamically adapt to the local marketization process. Thus, we propose the following hypothesis.

Hypothesis $\mathbf{5}$ (H5). The low-carbon regulation intensity can strengthen the relationship between green innovation and green total factor productivity.

Meanwhile, the green investment impacts GTFP through market-oriented means, as the low-carbon marketization index accelerates the free flow of green factors. Although, market factor may be the weakening element in carbon capture and distribution technology for the loss control [35], but the low-carbon marketization index can loosen the intensity of the low-carbon regulation actually in the same way. It will avoid price speculation and negative demonstration effect that is caused by inefficient competition. Both of them can improve capital utilization efficiency [29]. As a result of these marketization activities, the negative effects of rent-seeking behavior can be eliminated and the allocation efficiency of green elements can be improved. Due to the simplification of the processes of environmental impact assessment and environmental protection, the green investment may lack macro-guidance. Then, the low-carbon regulation has been relaxed to a certain extent. This will diminish the positive impact of green investments on GTFP [36]. Thus, we propose the following hypothesis.

Hypothesis 6 (H6). The low-carbon marketization index can weaken the relationship between green investment and green total factor productivity.

To sum up, the key to the market-oriented allocation reform of green elements is to deal with the interaction between the low-carbon marketization index and the low-carbon 
regulation intensity. The government should take some reasonable guiding measures to gradually eliminate the policy discrimination for enterprises, and the enterprises should effectively promote green innovation to harmonious development between the quality of green goals and the efficiency of green elements. Combining the above theoretical analysis and research assumptions, we construct a theoretical model as shown in Figure 1.

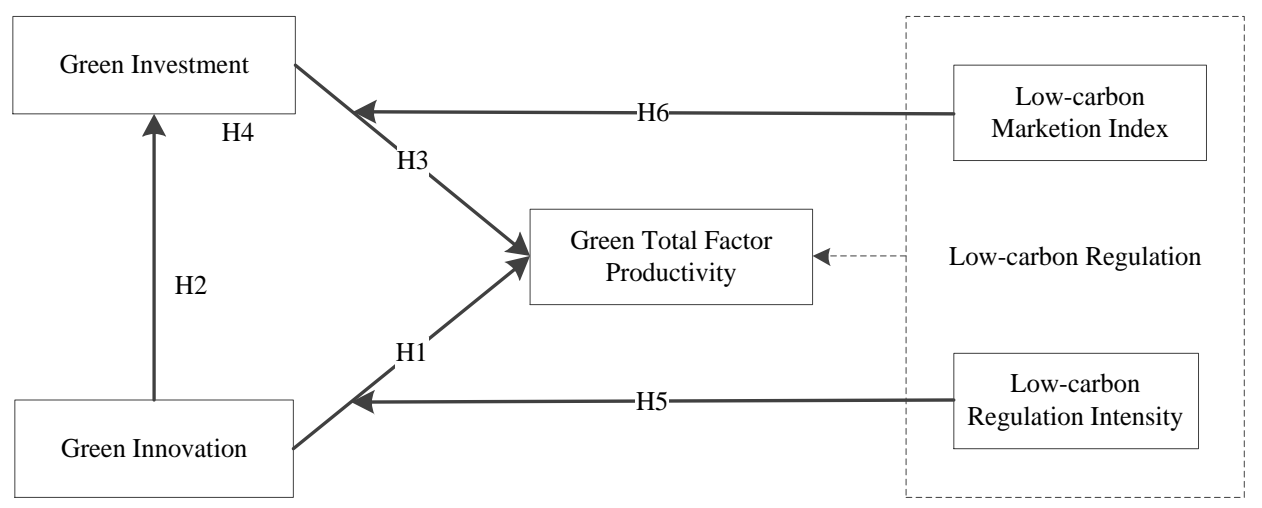

Figure 1. The effects of green total factor productivity by low-carbon regulation instruments. Source(s): (Authors' elaboration).

\section{Materials and Methods}

\subsection{Econometric Models}

Based on the above theoretical analysis and the research of Hulten et al. [37], the parameter of green productivity is taken as a multivariable function combination. Firstly, enterprises are reluctant to take the initiative in carbon mitigation without environment regulation. Referring to the research of Tao and Zhou [38], we selected the green technology, capital, and knowledge capital factors as the main variables to explain green performance. Then, the undesired output of environmental factors should be considered based on the input output of enterprises. Referring to the research of Zhang et al. [39] and Tong et al. [40], we choose the measuring method of GTFP to test our hypotheses. Finally, take the low-carbon regulation as the necessary external constraint for enterprises to carry out green investment and green innovation activities. According to the characteristics of the Cobb-Douglas production function, we set up a model of GTFP as follows:

$$
\operatorname{GTFP}_{i t}=A_{i 0} e^{\mu_{i} t} T_{i t}^{\mu_{i}} W_{i t}^{\delta_{i}} M_{i t}^{\rho_{i}}
$$

where the dependent variable of GTFP represents green total factor productivity regressed on three variables. As the independent variable $T$ is green innovation for green technology factors; the mediating variable $W$ is a green investment for green capital factors; and the moderating variable $M$ is low-carbon regulation for green knowledge capital factors. $i$ and $t$ represent the sample and the year variable respectively. $A_{i 0}$ is the initial productivity. $\mu_{i}, \delta_{i}$, and $\rho_{i}$ are factors that affect the green allocation efficiency of green factors. Then, drawing on the research of Wang and Yang [41], we use the transcendental logarithmic production function to test the effects of these factors on GTFP, and extend the specified Equation (1) to arrive at Equation (2) as follows:

$$
\begin{aligned}
\ln \mathrm{GTFP}_{i t}= & \alpha+\mu_{1} \ln T_{i t}+\frac{1}{2} \mu_{2}\left(\ln T_{i t}\right)^{2}+\delta_{1} \ln W_{i t}+\frac{1}{2} \delta_{2}\left(\ln W_{i t}\right)^{2}+\rho_{1} \ln M_{i t}+ \\
& \frac{1}{2} \rho_{2}\left(\ln M_{i t}\right)^{2}+\mu_{3} \ln \text { Controls }_{i t}+\eta_{1} \ln T_{i t} \times \ln M_{i t}+\eta_{2} \ln W_{i t} \times \ln M_{i t}+\varepsilon_{i t}
\end{aligned}
$$

where the moderating variable $\ln M$ is low-carbon regulation instruments, including lowcarbon marketization index (lnmark), low-carbon regulation intensity $(\ln r e g u)$, and their interaction $(\ln$ mark $\times \ln r e g u)$. lnControls represents a group of control variables that are random perturbations. $\varepsilon$ represents a random interference term. Other symbolic expressions are consistent with Equation (1). 


\subsection{Data and Variables}

We use panel data of 170 cities in China from 2006 to 2017. After data modification, we got 2040 effective samples.

(i) GTFP: the method of DEAP-Malmquist index is used to measure the enterprises' environmental efficiency, the industrial GTFP, or agricultural GTFP [42]. Thus, we used the DEAP- Malmquist index to measure GTFP with the input of urban employment, fixed assets, energy consumption, and the output of regional GDP, carbon dioxide emission, and sulfur dioxide emission.

(ii) Green innovation: drawing on the practices of Dong and Wang [43], we use the green patent code of the World Intellectual Property Organization by a search for the patent inquiry website of the China Intellectual Property Office. The green patent data of each city was obtained manually by searching the IPC classification code, and the address of the patent applicant can indicate the green innovation.

(iii) Green investment: the enterprise goal of green investment is mainly aimed at controlling industrial pollution to improve environmental quality. Thus, the capital input of industrial pollution control in various regions is measured by the amount of completed investment of industrial pollution control in Chinese cities.

(iv) Low-carbon regulation instruments: the low-carbon marketization index took the marketization index as the proxy variable which refers to the report of the marketization index of China's provinces, and we adopt the trend analysis method to revise and convert the GDP ratio of cities compared to their provinces. Meanwhile, according to the method of reference [43], the low-carbon regulation intensity is measured by calculating the average of sulfur dioxide emission and dust emission composite index of each city.

(v) Control variables: we mainly considered the green elements which affect the allocation efficiency. 1. Industrial convergence degree. As Jia and Zhang [33] considered that the regional green industry agglomeration is helpful to promote the overall green innovation level. Therefore, we use the entropy index method to calculate the industrial convergence degree to characterize the regional green agglomeration level; 2. Environmental quality. The research by Liao et al. [27] shows that green investment can improve environmental quality by reducing environmental pollution, such as carbon dioxide emission and sulfur dioxide emission. Therefore, we use sulfur dioxide emission to characterize the environmental quality. The lower the sulfur dioxide emission, the higher the environmental quality; 3. Capital structure. As the research of Chen and Feng [4] shows that environmental regulation has a more significant impact on the investment efficiency of green governance in nonstate-owned enterprises. We use the method of gray relational grade to calculate the industrial capital structure with state-owned capital as a reference; 4. Human capital stock. The study of Zhou and Li [44] confirmed that human capital has a significant impact on high-tech innovation output. Therefore, the human capital stock was calculated by the number of urban workers and average years of schooling.

All the above variables were taken into logarithm as dimensionless treatment.

\section{Results and Discussion}

\subsection{The Test Steps}

Before the empirical analysis, we first took variables to dimensionless and both of their interactive terms are decentralized. Then, the panel unit root was tested through LLC, IPS, and ADF methods. The results confirmed that all of them are stationary. Furthermore, we used the variance expansion factor to test the VIF value. The results showed that the mean VIF value range from 1.75 to 2.88 and all the single VIF value are less than 10 . Therefore, we made a judgment of no serious multi-collinearity problems in the models.

Then, the empirical analysis was made to test these hypotheses. Firstly, we used the ordinary least squares (OLS) method to study the mediating effect of green investment on the relationship between green innovation and GTFP (Table 1); Secondly, we discussed 
the mediating effect between green innovation and GTFP under the effect of low-carbon regulation intensity (Table 2); Finally, we further investigated the "moderated mediating effect" of green investment on GTFP under the low-carbon marketization index (Table 3).

Table 1. The result of mediating effect test of green investment.

\begin{tabular}{|c|c|c|c|c|c|c|c|}
\hline & & \multicolumn{2}{|c|}{ Green Investment } & \multicolumn{4}{|c|}{ GTFP } \\
\hline & & (1) & (2) & (3) & (4) & (5) & (6) \\
\hline \multirow{4}{*}{$\begin{array}{c}\text { Control } \\
\text { Variables }\end{array}$} & Industrial convergence degree & $\begin{array}{c}-9.080^{* * *} \\
(-17.30)\end{array}$ & $\begin{array}{c}-6.618^{* * *} \\
(-13.10)\end{array}$ & $\begin{array}{l}0.249 \\
(1.14)\end{array}$ & $\begin{array}{l}-0.314 \\
(-1.47)\end{array}$ & $\begin{array}{l}-0.394 \text { * } \\
(-1.73)\end{array}$ & $\begin{array}{c}-0.518^{* *} \\
(-2.35)\end{array}$ \\
\hline & Capital structure & $\begin{array}{c}0.405^{* * *} \\
(15.46)\end{array}$ & $\begin{array}{c}0.162^{* * *} \\
(6.15)\end{array}$ & $\begin{array}{l}0.005 \\
(0.50)\end{array}$ & $\begin{array}{c}0.061^{* * *} \\
(6.08)\end{array}$ & $\begin{array}{c}0.041^{* * *} \\
(4.03)\end{array}$ & $\begin{array}{c}0.070 * * * \\
(6.77)\end{array}$ \\
\hline & Human capital stock & $\begin{array}{c}-0.080 * * * \\
(-5.71)\end{array}$ & $\begin{array}{c}-0.059 * * * \\
(-4.65)\end{array}$ & $\begin{array}{l}-0.002 \\
(-0.37)\end{array}$ & $\begin{array}{l}-0.007 \\
(-1.22)\end{array}$ & $\begin{array}{l}-0.007 \\
(-1.14)\end{array}$ & $\begin{array}{l}-0.008 \\
(-1.35)\end{array}$ \\
\hline & Environmental quality & $\begin{array}{c}0.350 * * * \\
(13.48)\end{array}$ & $\begin{array}{c}0.320^{* * *} \\
(12.51)\end{array}$ & $\begin{array}{l}0.007 \\
(0.82)\end{array}$ & $\begin{array}{l}0.013 \\
(1.53)\end{array}$ & $\begin{array}{c}0.023 * * \\
(2.41)\end{array}$ & $\begin{array}{c}0.016 \text { * } \\
(1.79)\end{array}$ \\
\hline \multirow{3}{*}{$\begin{array}{c}\text { Independent } \\
\text { Variables }\end{array}$} & Green innovation & & $0.191^{* * *}$ & & $\underset{* * *}{-0.041}$ & & $-0.034^{* * *}$ \\
\hline & & & $(23.27)$ & & $(-12.09)$ & & $(-8.61)$ \\
\hline & Square of green innovation & & & & $\begin{array}{c}-0.003 \text { ** } \\
(-2.35)\end{array}$ & & $\begin{array}{l}-0.001 \\
(-0.55)\end{array}$ \\
\hline \multirow{9}{*}{$\begin{array}{l}\text { Mediating } \\
\text { Variables }\end{array}$} & Green investment & & & & & $-\underset{* * *}{0.063}$ & $-0.029^{* * *}$ \\
\hline & 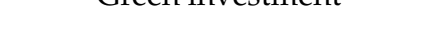 & & & & & $(-7.24)$ & $(-2.85)$ \\
\hline & Square of oreen investment & & & & & $-\underset{* * *}{0.020}$ & $-0.018^{* * *}$ \\
\hline & & & & & & $(-4.52)$ & $(-4.20)$ \\
\hline & time & $\mathrm{Y}$ & $\mathrm{Y}$ & $\mathrm{Y}$ & Y & $\mathrm{Y}$ & $\mathrm{Y}$ \\
\hline & $\mathrm{N}$ & 2040 & 2040 & 2040 & 2040 & 2040 & 2040 \\
\hline & VIF & 1.75 & 1.76 & 1.75 & 1.73 & 1.88 & 1.99 \\
\hline & $\Delta \mathrm{R}^{2}$ & 0.496 & 0.593 & 0.004 & 0.056 & 0.040 & 0.067 \\
\hline & $\mathrm{F}$ & 120.609 & 170.795 & 1.580 & 11.363 & 7.372 & 11.326 \\
\hline
\end{tabular}

(i) * significance at $0.05,{ }^{* *}$ significance at $0.01,{ }^{* * *}$ significance at 0.001 . (ii) $t$ value in parentheses. Source(s): (Authors' elaboration).

Table 2. The result of mediated moderating effect test.

\begin{tabular}{|c|c|c|c|c|c|c|c|c|c|}
\hline & & \multicolumn{2}{|c|}{ Green Investment } & \multicolumn{6}{|c|}{ GTFP } \\
\hline & & (1) & (2) & (3) & (4) & (5) & (6) & (7) & (8) \\
\hline \multirow{8}{*}{$\begin{array}{c}\text { Control } \\
\text { Variables }\end{array}$} & \multirow[t]{2}{*}{ Industrial convergence degree } & -4.125 & -3.983 & 0.165 & -0.116 & 0.014 & -0.209 & 0.166 & -0.102 \\
\hline & & $(-8.07)$ & $(-7.94)$ & $(0.74)$ & $(-0.52)$ & $(0.06)$ & $(-0.93)$ & $(0.74)$ & $(-0.46)$ \\
\hline & \multirow{2}{*}{ Capital structure } & -0.094 & -0.060 & 0.002 & 0.005 & 0.013 & 0.016 & 0.005 & 0.007 \\
\hline & & $(-3.28)$ & $(-2.04)$ & $(0.18)$ & $(0.38)$ & $(1.05)$ & $(1.25)$ & $(0.43)$ & $(0.52)$ \\
\hline & \multirow{2}{*}{ Human capital stock } & $\underset{* * *}{-0.067}$ & $\underset{* * *}{-0.070}$ & -0.008 & $\underset{*}{-0.010}$ & -0.009 * & $-\underset{* *}{-0.012}$ & -0.008 & $-0.010^{*}$ \\
\hline & & $(-5.85)$ & $(-6.24)$ & $(-1.33)$ & $(-1.68)$ & $(-1.65)$ & $(-2.02)$ & $(-1.41)$ & $(-1.75)$ \\
\hline & \multirow{2}{*}{ Environmental quality } & 0.051 & $0.076^{*}$ & $-\underset{* * *}{0.066}$ & $-\underset{* * *}{0.058}$ & -0.073 & -0.066 & $-\underset{* * *}{-0.068}$ & $-\underset{* * *}{0.060}$ \\
\hline & & $(1.30)$ & $(1.86)$ & $(-4.05)$ & $(-3.59)$ & $(-4.49)$ & $(-4.05)$ & $(-4.25)$ & $(-3.77)$ \\
\hline \multirow{5}{*}{$\begin{array}{l}\text { Moderating } \\
\text { Variables }\end{array}$} & Low-carbon marketization index & $\begin{array}{c}1.154^{* * *} \\
(12.05)\end{array}$ & $\begin{array}{c}1.243^{* * *} \\
(13.50)\end{array}$ & $\begin{array}{l}0.008 \\
(0.17)\end{array}$ & $\begin{array}{l}0.078 \\
(1.54)\end{array}$ & $\begin{array}{l}-0.004 \\
(-0.08)\end{array}$ & $\begin{array}{l}0.059 \\
(1.16)\end{array}$ & $\begin{array}{l}-0.005 \\
(-0.10)\end{array}$ & $\begin{array}{l}0.064 \\
(1.25)\end{array}$ \\
\hline & \multirow[t]{2}{*}{ Low-carbon marketization intensity } & $0.270 * * *$ & $0.238^{* * *}$ & 0.080 & $\underset{* * *}{0.086}$ & $0.078^{* * *}$ & $0.083^{* * *}$ & $\underset{* * *}{0.095}$ & $0.099^{* * *}$ \\
\hline & & $(9.51)$ & $(8.05)$ & $(6.33)$ & $(6.42)$ & $(6.10)$ & (6.13) & $(7.19)$ & $(7.03)$ \\
\hline & \multirow{2}{*}{$\begin{array}{l}\text { Interaction of low-carbon } \\
\text { marketization index and low-carbon } \\
\text { regulation intensity }\end{array}$} & -0.026 & $-\underset{* *}{-0.120}$ & $-\underset{* * *}{-0.098}$ & $-\underset{* * *}{-0.067}$ & 0.006 & 0.025 & -0.091 & -0.064 \\
\hline & & $(-0.51)$ & $(-2.27)$ & $(-4.44)$ & $(-2.79)$ & $(0.26)$ & $(1.02)$ & $(-4.16)$ & $(-2.70)$ \\
\hline
\end{tabular}


Table 2. Cont.

\begin{tabular}{|c|c|c|c|c|c|c|c|c|c|}
\hline & & \multicolumn{2}{|c|}{ Green Investment } & \multicolumn{6}{|c|}{ GTFP } \\
\hline & & (1) & (2) & (3) & (4) & (5) & (6) & (7) & (8) \\
\hline \multirow{8}{*}{$\begin{array}{c}\text { Independent } \\
\text { Variables }\end{array}$} & Green innovation & $0.117^{* * *}$ & $0.112 * * *$ & $\underset{* * *}{-0.050}$ & $\underset{* * *}{-0.043}$ & $\underset{* * *}{-0.045}$ & $-\underset{* * *}{0.039}$ & $\underset{* * *}{-0.043}$ & $\underset{* * *}{-0.038}$ \\
\hline & & $(12.92)$ & $(12.55)$ & $(-12.26)$ & $(-10.37)$ & $(-11.25)$ & $(-9.53)$ & $(-9.89)$ & $(-8.57)$ \\
\hline & Square of green innovation & & & $\begin{array}{c}-0.008 \\
* * *\end{array}$ & $\begin{array}{c}-0.007 \\
* * *\end{array}$ & -0.000 & 0.001 & $\begin{array}{c}-0.007 \\
* * *\end{array}$ & $\begin{array}{c}-0.006 \\
* * *\end{array}$ \\
\hline & & & & $(-5.48)$ & $(-4.89)$ & $(-0.19)$ & $(0.36)$ & $(-4.35)$ & $(-4.00)$ \\
\hline & Interaction of green innovation and & $0.024^{* * *}$ & & $\underset{* * *}{0.015}$ & $\underbrace{0.017}_{* * *}$ & & & $\underset{* * *}{0.015}$ & $0.017^{* * *}$ \\
\hline & low-carbon regulation intensity & $(4.95)$ & & $(5.44)$ & $(6.35)$ & & & $(5.56)$ & $(6.42)$ \\
\hline & Interaction of green innovation and & & $0.253^{* * *}$ & & & $\underset{* * *}{-0.093}$ & $\underset{* * *}{-0.081}$ & & \\
\hline & low-carbon marketization index & & $(7.71)$ & & & $(-5.31)$ & $(-4.68)$ & & \\
\hline \multirow{12}{*}{$\begin{array}{c}\text { Mediating } \\
\text { Variables }\end{array}$} & Interaction of square of green & & & & & & & $\underset{* * *}{-0.003}$ & $\underset{* * *}{-0.002}$ \\
\hline & $\begin{array}{l}\text { innovation and low-carbon } \\
\text { regulation intensity }\end{array}$ & & & & & & & $(-3.78)$ & $(-2.98)$ \\
\hline & reguiation intensity & & & & -0.052 & & -0.044 & & -0.050 \\
\hline & Green investment & & & & $* * *$ & & $* * *$ & & $* * *$ \\
\hline & & & & & $(-4.78)$ & & $(-3.99)$ & & $(-4.63)$ \\
\hline & Square of green investment & & & & $\begin{array}{c}-0.017 \\
* * *\end{array}$ & & $-\underset{* *}{0.012}$ & & $-\underset{* * *}{0.016}$ \\
\hline & & & & & $(-3.40)$ & & $(-2.32)$ & & $(-3.04)$ \\
\hline & time & $\mathrm{Y}$ & Y & Y & $\mathrm{Y}$ & $\mathrm{Y}$ & $\mathrm{Y}$ & Y & $\mathrm{Y}$ \\
\hline & $\mathrm{N}$ & 2040 & 2040 & 2040 & 2040 & 2040 & 2040 & 2040 & 2040 \\
\hline & VIF & 2.53 & 2.54 & 2.54 & 2.61 & 2.54 & 2.61 & 2.63 & 2.69 \\
\hline & $\Delta \mathrm{R}^{2}$ & 0.653 & 0.658 & 0.083 & 0.100 & 0.082 & 0.092 & 0.088 & 0.103 \\
\hline & $\mathrm{F}$ & 215.245 & 211.117 & 13.518 & 15.348 & 12.830 & 13.675 & 13.770 & 14.981 \\
\hline
\end{tabular}

(i) * significance at $0.05,{ }^{* *}$ significance at $0.01, * * *$ significance at 0.001 . (ii) $t$ value in parentheses. Source(s): (Authors' elaboration).

Table 3. The result of mediated moderating effect test.

\begin{tabular}{|c|c|c|c|c|c|c|c|}
\hline & & $\begin{array}{c}\text { Green } \\
\text { Investment }\end{array}$ & & & GTFP & & \\
\hline & & (1) & (2) & (3) & (4) & (5) & (6) \\
\hline \multirow{4}{*}{$\begin{array}{l}\text { Moderating } \\
\text { Variables }\end{array}$} & Low-carbon marketization index & $\begin{array}{c}1.236 * * * \\
(12.90)\end{array}$ & $\begin{array}{l}0.025 \\
(0.50)\end{array}$ & $\begin{array}{c}0.091^{*} \\
(1.75)\end{array}$ & $\begin{array}{l}0.030 \\
(0.60)\end{array}$ & $\begin{array}{l}0.007 \\
(0.13)\end{array}$ & $\begin{array}{l}-0.009 \\
(-0.17)\end{array}$ \\
\hline & Low-carbon regulation intensity & $\begin{array}{c}0.265^{* * *} \\
(9.30)\end{array}$ & $\begin{array}{c}0.072 * * * \\
(5.57)\end{array}$ & $\begin{array}{c}0.078^{* * * *} \\
(5.74)\end{array}$ & $\begin{array}{c}0.081^{* * * *} \\
(5.92)\end{array}$ & $\begin{array}{c}0.080^{* * *} \\
(5.76)\end{array}$ & $\begin{array}{c}0.081^{* * *} \\
(5.93)\end{array}$ \\
\hline & $\begin{array}{l}\text { Interaction of low-carbon } \\
\text { marketization index and low-carbon }\end{array}$ & 0.077 & $\underset{* * *}{-0.053}$ & -0.024 & 0.041 * & -0.010 & 0.044 * \\
\hline & $\begin{array}{l}\text { marketization indion and iow-carbon } \\
\text { regulation ity }\end{array}$ & $(1.62)$ & $(-2.67)$ & $(-1.06)$ & $(1.67)$ & $(-0.28)$ & $(1.81)$ \\
\hline \multirow{5}{*}{$\begin{array}{l}\text { Independent } \\
\text { Variables }\end{array}$} & Green innovation & $0.114^{* * *}$ & $\underset{* * *}{-0.048}$ & $-\underset{* * *}{-0.041}$ & $-\underset{* * *}{-0.039}$ & $\underset{* * *}{-0.041}$ & $-\underset{* * *}{0.039}$ \\
\hline & & (12.65) & $(-11.94)$ & $(-10.02)$ & $(-9.36)$ & $(-9.63)$ & $(-9.29)$ \\
\hline & Square of green innovation & & $\underset{* * *}{-0.004}$ & $-0.002 *$ & $-0.002 *$ & $-\underset{* * *}{-0.004}$ & $-0.003 *$ \\
\hline & & & $(-2.85)$ & $(-1.78)$ & $(-1.77)$ & $(-2.92)$ & $(-1.95)$ \\
\hline & Green investment & & & $\underset{* * *}{-0.050}$ & $-\underset{* * *}{-0.038}$ & $\underset{* * *}{-0.043}$ & $-\underset{* * *}{0.051}$ \\
\hline \multirow{3}{*}{$\begin{array}{l}\text { Mediating } \\
\text { Variables }\end{array}$} & & & & $(-4.50)$ & $(-3.53)$ & $(-3.97)$ & $(-4.35)$ \\
\hline & Square of green investment & & & $-\underset{* *}{-0.013}$ & 0.004 & $-0.018^{*}$ & -0.003 \\
\hline & & & & $(-2.52)$ & $(0.56)$ & $(-1.92)$ & $(-0.43)$ \\
\hline
\end{tabular}


Table 3. Cont.

\begin{tabular}{|c|c|c|c|c|c|c|c|}
\hline & & $\begin{array}{c}\text { Green } \\
\text { Investment }\end{array}$ & & & GTFP & & \\
\hline & & (1) & (2) & (3) & (4) & (5) & (6) \\
\hline \multirow[t]{7}{*}{$\begin{array}{l}\text { Interactive } \\
\text { Term }\end{array}$} & $\begin{array}{l}\text { Interaction of green investment and } \\
\text { low-carbon marketization index } \\
\text { Interaction of green investment and } \\
\text { low-carbon regulation intensity } \\
\text { Interaction of green investment, } \\
\text { low-carbon regulation intensity, and } \\
\text { low-carbon marketization index } \\
\text { Interaction of square of green } \\
\text { investment and low-carbon } \\
\text { marketization index }\end{array}$ & & & & $\begin{array}{c}-0.198 \\
* * * \\
(-4.72)\end{array}$ & $\begin{array}{c}-0.145 \\
* * * \\
(-2.80) \\
0.024^{* * *} \\
(3.18) \\
0.041^{* * *} \\
(3.11)\end{array}$ & $\begin{array}{c}-0.179 \\
* * * \\
(-4.27)\end{array}$ \\
\hline & Controls & $\mathrm{Y}$ & $\mathrm{Y}$ & $\mathrm{Y}$ & $\mathrm{Y}$ & $\mathrm{Y}$ & $\mathrm{Y}$ \\
\hline & time & $\mathrm{Y}$ & Y & $\mathrm{Y}$ & Y & $\mathrm{Y}$ & $\mathrm{Y}$ \\
\hline & $\mathrm{N}$ & 2040 & 2040 & 2040 & 2040 & 2040 & 2040 \\
\hline & VIF & 2.56 & 2.52 & 2.59 & 2.72 & 2.88 & 2.78 \\
\hline & $\Delta \mathrm{R}^{2}$ & 0.649 & 0.071 & 0.084 & 0.093 & 0.102 & 0.096 \\
\hline & $\mathrm{F}$ & 218.593 & 12.048 & 13.186 & 13.925 & 15.926 & 14.224 \\
\hline
\end{tabular}

(i) ${ }^{*}$ significance at $0.05,{ }^{* *}$ significance at $0.01,{ }^{* * *}$ significance at 0.001 . (ii) $t$ value in parentheses. Source(s): (Authors' elaboration).

\subsection{Mediating Effect Test of Green Investment}

According to the research of four mediator variable equations by Baron and Kenny [45], we examine whether a green investment has a mediating role in the relationship between green innovation and GTFP. Model 2 in Table 1 shows that green innovation has a significant positive effect on green investment $(\beta=0.191, p<0.001)$. This is because the green transformation results require a large number of green investments, and the results of green technology with good returns can also attract more green capitals to be put on the good performance progress. This result supports Hypothesis 2.

The regression results of model 3 show that the effect of four control variables on GTFP is not significant. Then we put the independent variables of green innovation and its quadratic terms into the regression equation (Model 4$)$. The results show that both the green innovation and its quadratic coefficient are significantly negative ( $\beta=0.041$, $p<0.001 ; \beta=0.003, p<0.01)$. This indicates that there is an inverted U-shaped relationship between green innovation and GTFP. That is to say, green productivity can be improved by increasing green technology achievements, but the transformation of green technology achievements would increase the cost of green productivity. Thus, Hypothesis 1 is valid.

Meanwhile, there is a significant inverted U-shaped relationship between green investment and GTFP (Model 5). The coefficients of green investment and its second term are 0.063 and 0.020 respectively $(p<0.001)$. Therefore, the green investment also makes the efficiency increase first and then decrease. This means Hypothesis 3 is confirmed.

Finally, we investigate the effects of green innovation and green investment on GTFP. As the result shows in model 6, green investment and its secondary terms have significant negative effects with the coefficients at 0.029 and $0.018(p<0.001)$. At this point, the coefficient of green innovation is also significant $(\beta=0.034, p<0.001)$, but the quadratic coefficient is not significant. The above empirical results show that green investment plays a partial mediating role in the relationship between green innovation and GTFP. This means that the transformation of green technology achievements in the process of enhancing the green factor allocation efficiency. That is to say, Hypothesis 4 is confirmed by the need for green capital elements to participate, and they play an important transmission role in that relationship.

Each control variable of human capital stock, capital structure, and industrial convergence degree have a negative effect on green investment. However, the role of environ- 
mental quality is different, which is positively related to the green investment and also negatively related to GTFP. The main reason is that enterprises may pay more attention to the protection of environmental quality under the pressure of low-carbon regulation. Thus, that more private capital is introduced into the field of the green industry, and more green technology is used for clean production. Therefore, environmental quality has made a prerequisite for the production and operation of enterprises. It can also enhance the allocation efficiency of green elements to improve environmental quality.

\subsection{Moderating Effect Test of Low-Carbon Regulation Instruments}

Hypothesis 5 suggests that the great intensity of low-carbon regulation can strengthen the impact of green innovation on GTFP. We use the method of hierarchical regulatory regression to test the moderating effect with the interactive terms. Firstly, according to the research method of Wen et al. [46], the moderating effect of low-carbon regulation intensity is tested as follows: According to the empirical results of Table 1, the green innovation has a significant inverted U-shaped effect on GTFP. In Table 2, we find that the interaction coefficient between low-carbon regulation intensity and green innovation is significantly positive $(\beta=0.024, p<0.001$, Model 1$)$. This indicates that the increasing of low-carbon regulation intensity can promote the green innovation level. Then, the interaction between green innovation and low-carbon regulation intensity was added to Model 3 with GTFP as independent variables, and the interaction coefficient is still significantly positive $(\beta=0.015$, $p<0.001)$. The empirical results show that green investment and its second term have significant negative effects on GTFP, with coefficients of 0.052 and 0.017 respectively. Both of them are significant at 0.001 (Model 4). Moreover, Model 6 and Model 8 also identified a significant inverted U-shaped relationship between green investment and GTFP.

In the same way, the low-carbon marketization index was put into the model as a moderating variable. The empirical results show that the interaction between green investment and low-carbon marketization index has a significant positive effect on green investment $(\beta=0.253, p<0.001$, Model 2$)$, and the interaction term has a significantly negative effect on GTFP ( $\beta=0.093, p<0.001$, Model 5). It concludes that low-carbon regulation intensity and low-carbon marketization index are both mediating variables; the former significantly attenuating the negative effects of green innovation on GTFP; and the latter significantly enhancing the negative effects. Thus, Hypothesis 5 is supported.

Hypothesis 6 suggests that the low-carbon marketization index is a "moderated mediating effect", which can weaken the relationship between green investment and GTFP. According to the research method of Wen et al. [46], we made the empirical test to be reflected in Table 3. The steps are as follows: (i) the regression of green investment on green innovation and the low-carbon marketization index is shown in Model 1 . The effect of green innovation on green investment is significantly positive $(\beta=0.114, p<0.001)$; (ii) a regression of GTFP regression to green innovation and low-carbon marketization index in Model 2. The coefficient of green innovation quadratic item is significantly negative $(\beta=0.004, p<0.001)$; (iii) a regression of GTFP to green innovation, low-carbon marketization index, and green investment in Model 3. The results show that green investment and its second term have significant negative effects on GTFP, with coefficients of 0.050 and 0.013 respectively; (iv) a regression of GTFP to green innovation, low-carbon marketization index, green investment, and green investment interactions in Model 4. The results show that the interaction term coefficient is significantly negative $(\beta=0.198$, $p<0.001)$.

Therefore, it concludes that the low-carbon marketization index plays a significant role in regulating the relationship between green investment and GTFP. Then, the interactive term of low-carbon marketization index and low-carbon regulation intensity was put into the regression equation (Model 5). The result shows that the coefficient of the interaction is still significantly positive $(\beta=0.041, p<0.001)$. That is to say, the negative effect of green investment on GTFP is strengthened by the low-carbon marketization index, while the negative effect is weakened by the low-carbon regulation intensity. 
The control variables are the same regression results as shown in Table 3. Referring to the U-shaped relationship of Richard et al. [47], the interactive term between mediating variables and green innovation quadratic term (Model 7 of Table 2) is introduced to further determine the moderating effect of low-carbon regulation on GTFP nonlinearity. It is found that the coefficient of interactive term between green innovation quadratic item and low-carbon regulation intensity was significantly negative $(\beta=0.003, p<0.001)$, and the green investment and its quadratic item coefficient in Model 8 are also significantly negative $(\beta=0.050, p<0.001 ; \beta=0.016, p<0.001)$.

It shows that the low-carbon regulation intensity makes a steeper curve of the inverted U-shaped relationship between green innovation and GTFP. That is to say, the higher GTFP can be achieved with less green innovation. Continuing to put an interactive term of green investment quadratic term and low-carbon marketization index into the equation (Model 6 of Table 3), we found that the coefficient of the interactive term is significantly positive $(\beta=0.043, p<0.001)$. This shows that the low-carbon marketization index makes a smoother curve of the inverted U-shaped relationship between green investment and GTFP. That is to say, compared with the moderating effect of low-carbon regulation intensity, the low-carbon marketization index has a relatively weak moderating effect on GTFP. Thus, Hypothesis 6 also passes the test.

The main reasons for the weakening moderator effect of the low-carbon marketization index are as follows: Firstly, enterprises have to pay additional costs to reduce pollution. The profit-seeking nature of green capital causes enterprises to consider self-interest. Enterprises will inevitably reduce the intrinsic motivation to fulfill their environmental responsibilities in the case of the relative reduction of the low-carbon regulation intensity. Then, enterprises prefer to choose industries that will give a high return with less investment and high-profit margin with low-risk, rather than green industries with a long return period and a high technological capability. Thus, enterprises' gain of the competitive advantage of green innovation comes from the "innovation compensation effect". It is more profitable than the competitors without green innovation. However, this comparative advantage will be changed by marketization. It will weaken the willingness of enterprises to carry out independent green innovation and green investment activities. Therefore, we should not relax the low-carbon regulation intensity but strengthen the interaction between them to maintain the balanced development of economic growth and environmental quality.

\subsection{Discussion of the Growth Curve of Green Total Factor Productivity}

Based on the research of the Porter Hypothesis, there are two growth phases of GTFP by the impact of low-carbon regulation. First is a negative phase of "cost compliance" and then a positive phase of "innovation compensation". Since then, scholars have developed this hypothesis to an academic debate, such as U-shaped, N-shaped, and V-shaped, and other contentions. The research of Chen [48] believed that China's GTFP is in a declining stage, which is approaching the "Porter inflection point". This study of the preceding article has confirmed that the inverted U-shaped pattern of GTFP is consistent with the conclusion of Chen [48]. Either the government regulation or the enterprise innovation expects to gain coordinated growth, which is increased by the compensation effect of green innovation. That is to say, there must be some force that can make the "Porter inflection point" change into a descending speed. However, the U-shaped curve (quadratic relation) may not fully explain this problem. To further explore the relationships among green innovation, green investment, and GTFP, we can see that the growth curve has not only an inverted U-shaped but also positive U-shaped features. Thus, considering the theoretical basis and function properties, this paper put three terms of green innovation and green investment into the model. The results showed that both of the three terms are significant under 0.001 with coefficients of 0.002 and 0.008 , respectively. The empirical results mean that GTFP is undulating by the impact of green innovation and green investment. 
First of all, we draw the growth curve of GTFP according to the empirical results of the relationship between the three variables (Figure 2a). Then, we can obtain the growth curve by cross-sectional treatment of GTFP (Figure 2b).

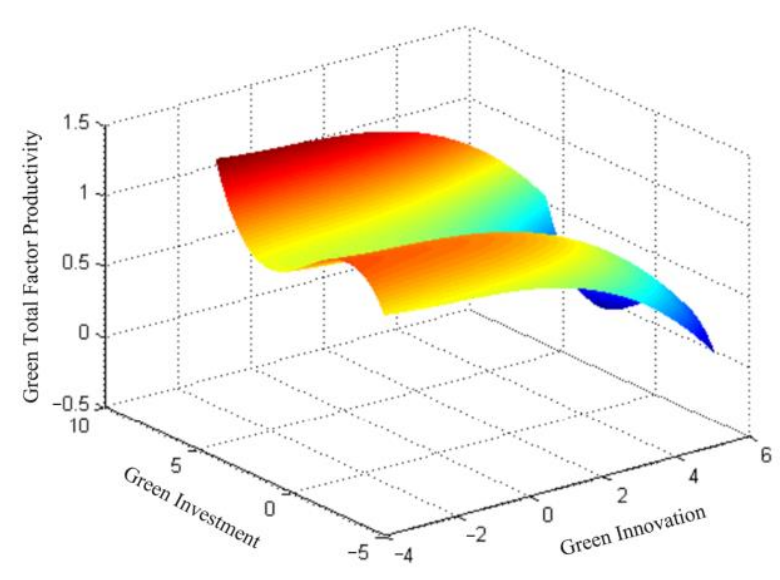

(a)

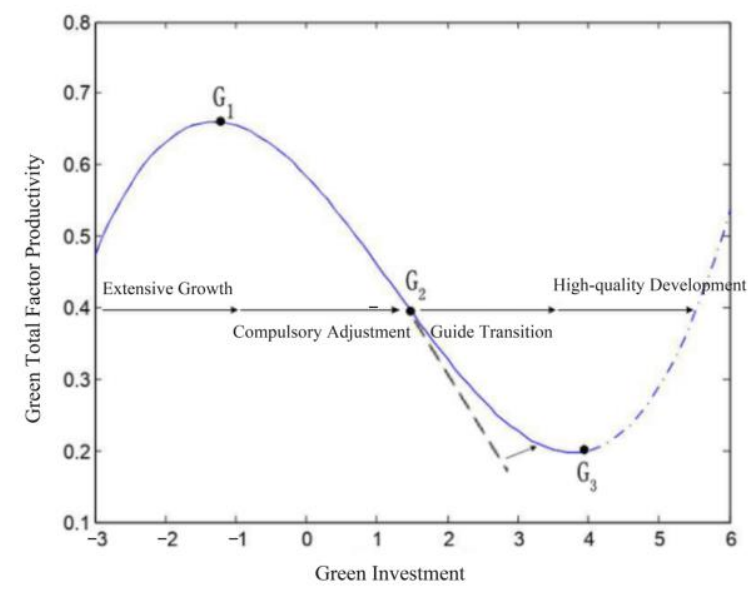

(b)

Figure 2. (a) The three-dimension of green total factor productivity. (b) The cross-section of green total factor productivity. Source(s): (Authors' elaboration).

Secondly, as we can see from Figure 2a, GTFP is increasing first, then decreasing, and finally increasing again. That is an inverted S-shaped type because the green investment has its influence and conduction function with the gradual increase of green innovation. In the growth curve of inverted S-shape, the first half is like an inverted U-shape, the second half is like a positive U-shape, and the whole curve is similar to an $\mathrm{N}$-shaped type. However, there are more than two inflection points. Therefore, the inverted S-shaped growth curve is more closely related to the actual situation.

Thirdly, as we can see from Figure 2b, there are three inflection points in the inverted S-shaped growth curve of GTFP. These inflection points are named G1, G2, and G3: (i) In the framework of low-carbon regulation analysis, G1 indicates that the enterprise performance is hard to make up for the loss. Because of the stock from the external pressure, the enterprise performance may change into a decreasing phase; (ii) In the economics framework, G2 is an economic inflection point because of the concave curve between G1 and G2 and the convex curve between the inflection point of G2 and G3; (iii) Meanwhile, G3 is the "Porter inflection point", which has taken a major turning to the increasing phase of GTFP.

Finally, these three inflection points have divided the growth curve of GTFP into four stages. (i) Before the inflection point of G1, there is an extensive growth model of factor resources because the rule of traditional factors has been diminishing returns. GTFP shows a slow-growth trend, which is named as a period of extensive growth; (ii) Between the inflection point of G1 and G2, the environmental quality is becoming more and more important because the low-carbon regulation forces enterprises to reduce carbon dioxide emissions. This external pressure may lead GTFP to a negative growth acceleration situation. The enterprise performance has been deceased with a long period of continual shocks of the low-carbon regulation, which is named as a period of compulsory adjustment; (iii) After the decreasing period, many companies want to find a new green road to deal with the negative pressure of low-carbon regulation. Then, they realize that green innovation can not only compensate for the green innovation cost but also enhance enterprise competitiveness. Thus, they will stimulate the independent power of green innovation and make the "tail" of the inverted U-shaped curve change gradually. Therefore, the negative growth trend of GTFP will be caused to slow down, which is named as a period of guide transition; (iv) The growth curve of GTFP will change from a downward phase to an 
upward trend when it is crossing the inflection point G3 ("Porter inflection point"). That is meaning the growth curve has achieved a green recovery process from the phase of "cost compliance" to the phase of "innovation compensation", which is named as a period of high-quality development.

In the extensive growth period and the compulsory adjustment period before the inflection point of G2, the growth curve of GTFP shows an inverted U-shaped pattern. It is consistent with the results of the empirical test. After crossing the inflection point of G2, the low-carbon regulation leads the enterprises to transform to the low-carbon pattern. It will reverse the negative growth trend of GTFP. That also can promote the improvement of ecological environment quality, which is closer to crossing the flection point of G3. The empirical results show that China's GTFP is close to G3. It is gradually crossing the "Porter inflection point" to a high-quality development stage.

\section{Conclusions}

To cope with an uncertain environment after the COVID-19 epidemic, this study proposed an integration model of green innovation and green investment by low-carbon regulation to search for the inflection point of green economic recovery. We explored this inflection point in a multi-stage growth curve of GTFP by using the panel data of 170 cities in China and finally found the following: (i) There is a significant positive correlation between green innovation and green investment, and both of them have an inverted Ushaped effect on GTFP; (ii) The inverted U-shaped curve will be smoother if low-carbon marketization index significantly weakened the relationship between green investment and GTFP; (iii) The inverted U-shaped curve can be steeper when the low-carbon regulation intensity significantly strengthened the relationship between green innovation and GTFP; (iv) Under these influences, GTFP shows an inverted S-shaped growth curve with three inflection points and four development stages. These results mean that the enterprise's motivation for green investment is boosted by the external pressure of the low-carbon regulation, which can drive the green productivity gradually change from a downward to an upward trend.

Therefore, the factors reform should not only highlight the decisive role of marketoriented allocation but also pay attention to the key role of environmental protection. It is necessary to bring environmental quality into the indicator system of the low-carbon regulation index. GTFP will cross the flection point quickly through the green investment increasing, which can push the environmental quality improving by the compensation effect of green innovation. The policy interventions should be devoted both to increasing the innovative process and to raising the diffusion of those industry branches and regions [49]. Then, the important implications are as follows: First of all, we should improve the enterprise abilities of green innovation with a clear market-oriented goal. Secondly, we should set up a fund platform and account policy of green investment to remove the restriction on green technology and capital flows. Last but not least, the transformation of green technology achievements should be encouraged to produce more and more green products, and a negative list system of nongreen industries also should be established to restrict nongreen products. Thus, all of these implemented policies will promote a coordination development path of green technology and capital elements to the flection point of green economic recovery.

As the lack of disclosed carbon data of listed companies makes the research many difficult, it is necessary to think more about the enterprise resilience represents the growth curve of GTFP changes to face with the interaction of low-carbon regulations. In further works, we should also pay more attention to the enterprise green innovation path to coordinated development for carbon mitigation, and carbon decision making between enterprises and government needs to achieve dynamic equilibrium. 
Author Contributions: Y.D. and Y.H. have equal contributions to this study. All authors were actively involved in the conceptualization, methodology, formal analysis, validation, and data curation. Moreover, Y.D. has written the original draft and Y.H. did the review and editing. All authors have read and agreed to the published version of the manuscript.

Funding: This research was funded by the Important Project of Higher Educational Humanity and Social Sciences Fund of Anhui Province with grant number SK2020A0486, and the Innovation and Entrepreneurship Training Program for College Students in Anhui Province with grant number s202010383171 and s202010383174 for the support during this research.

Institutional Review Board Statement: Not applicable.

Informed Consent Statement: Not applicable.

Data Availability Statement: Not applicable.

Acknowledgments: The authors are grateful to the editor of sustainability for their suggestions to this research.

Conflicts of Interest: The authors declare no conflict of interest.

\section{References}

1. Yüksel, S.; Dinçer, H.; Karakuş, H.; Ubay, G.G. The negative effects of carbon emission on FDI: A comparative analysis between E7 and G7 countries. Handbook of Research on Sustainable Supply Chain Management for the Global Economy. IGI Global. 2020, 20-35. [CrossRef]

2. Hu, Z.; Zhang, L.; Li, Y. Study on the effect of pollution charges to green total factor productivity: The impact evaluation of the policy based on generalized propensity score matching. Theory Pract. Financ. Econ. 2019, 6, 9-15.

3. Ren, S.; Zheng, J.; Liu, D.; Chen, X. Does emissions trading system improve firm's total factor productivity: Evidence from Chinese listed companies. China Ind. Econ. 2019, 5, 5-23.

4. Chen, Y.; Feng, J. Do corporate green investments improve environmental performance? evidence from the perspective of efficiency. Account. Res. 2020, 40, 179-192. [CrossRef]

5. Wang, J.; Liu, B. Environmental regulation and enterprises' TFP: An empirical analysis based on China' industrial enterprises data. China Ind. Econ. 2014, 3, 44-56.

6. Tang, X.; Gu, B.; Kang, Z.; Zong, D. Environmental regulation and total factor productivity of Chinese enterprises: Based on "energy saving and carbon reduction" policy. RED Manag. 2019, 3, 47-58.

7. Liang, G.; Yu, D.; Ke, L. An empirical study on dynamic evolution of industrial structure and green economic growth: Based on data from China's underdeveloped areas. Sustainability 2021, 13, 8154. [CrossRef]

8. Blackman, A.; Lahiri, B.; Pizer, W.; Planter, M.R.; Pina, C.M. Voluntary environmental regulation in developing countries: Mexico's clean industry program. J. Environ. Econ. Manag. 2010, 60, 182-192. [CrossRef]

9. Porter, M.E. America's green strategy. Sci. Am. 1991, 4, 168. [CrossRef]

10. Porter, M.E.; Linde, C. Toward a new conception of the environment competitiveness relationship. J. Econ. Perspect. 1995, 9 , 97-118. [CrossRef]

11. Jaffe, A.B.; Palme, R.K. Environmental regulation and innovation: A panel data study. Rev. Econ. Stat. 1997, 79, 610-619. [CrossRef]

12. Ambec, S.; Cohen, M.A.; Elgie, S.; Lanoie, P. The Porter hypothesis at 20: Can environmental regulation enhance innovation and competitiveness? Rev. Environ. Econ. Policy 2013, 7, 2-22. [CrossRef]

13. Chai, B.; Gao, J.; Pan, L.; Chen, Y. Research on the impact factors ofgreen economy of China: From the perspective of system and foreign direct investment. Sustainability 2021, 13, 8741. [CrossRef]

14. Zhao, J.; Dong, Z.; Hu, S. Factor matching and spatial difference of regional investment efficiency in China based on the decomposition of double-layer nested function. Stat. Res. 2019, 36, 100-113.

15. Stoever, J.; Weche, J.P. Environmental regulation and sustainable competitiveness: Evaluating the role of firm level green investments in the context of the Porter hypothesis. Environ. Res. Econ. 2018, 2, 429-455. [CrossRef]

16. Zhu, J. Technology absorption, government encouragement and China's total factor productivity promotion. China Ind. Econ. 2017, 33, 5-24.

17. Becker, M.C.; Knudsen, T.; Swedberg, R. Schumpeter's theory of economic development: 100 years of development. J. Evol. Econ. 2012, 22, 917-933. [CrossRef]

18. Wang, L.; Wang, H.; Dong, Z. Policy conditions for compatibility between economic growth and environmental quality: A test of policy bias effects from the perspective of the direction of environmental technological progress. Manag. World 2020, 3, 39-60.

19. Qian, J.; Li, J. Does technological progress effectively promote the energy saving and $\mathrm{CO}_{2}$ emission reduction? Stud. Sci. Sci. 2018, 1, 49-59.

20. Yuan, Y.; Chen, Z. Environmental regulation, green technology innovation and the transformation and upgrading of China's manufacturing industry. J. Clean. Prod. 2019, 10, 1902-1911. 
21. Lanjouw, J.; Mody, A. Innovation and the international diffusion of environmentally responsive technology. Res. Policy 1996, 25, 549-571. [CrossRef]

22. Zhang, X.; Wang, Y. Study on the effect of environmental regulation and $R \& D$ investment on green technology innovation. Sci. Technol. Prog. Policy 2017, 17, 111-119.

23. Pei, Y.; Zhu, Y.; Liu, S.; Jia, J. Environmental regulation and carbon emission: The mediation effect of technical efficiency. J. Clean. Prod. 2019, 11, 117599. [CrossRef]

24. Deng, L.; Liu, A. Environmental investment effect analysis: Based on the green total factor productivity perspective. Inq. Into Econ. Issues 2019, 8, 134-147.

25. Guo, T.; Zhao, S. Green technology bank: Exploration from China. China Popul. Res. Environ. 2019, 12, $131-137$.

26. Zhao, M.; Liu, F.; Wang, H.; Sun, W. Foreign direct investment, environmental regulation and urban green total factor productivity of the Yellow river basin. Econ. Geogr. 2020, 4, 38-47.

27. Liao, X.; Li, X.; Shi, X. Research on the influence mechanism of green investment on green welfare based on ecological civilization perspective. China Popul. Res. Environ. 2020, 2, 148-157.

28. Wang, R. Dynamic correlation between environmental regulation and green technology innovation: Retesting based on "Porter hypothesis". Sci. Technol. Manag. Res. 2020, 8, 243-250.

29. Liu, Y.; Yang, X.; Huang, M. Environmental regulation and green total factor productivity: Analysis of the mediating effect based on different technological progress path. Contemp. Econ. Manag. 2020, 6, 1-17.

30. Berman, E.; Bui, L. Environmental regulation and productivity: Evidence from oil refineries. Rev. Econ. Stat. 2001, 83, 498-510. [CrossRef]

31. Yuan, B.; Xiang, Q. Environmental regulation, industrial innovation and green development of Chinese manufacturing: Based on an extended CDM model. J. Clean. Prod. 2018, 176, 895-908. [CrossRef]

32. Cutter, B.; Deshazo, J.R. The environmental consequences of decentralizing the decision to decentralize. J. Environ. Econ. Manag. 2007, 53, 32-53. [CrossRef]

33. Jia, J.; Zhang, W. The path dependency of green technology innovation and environmental regulation analysis. Sci. Sci. Manag. S 2014, 5, 44-52.

34. Li, R. Does marketization improve the effectiveness of environmental regulation? Retest the "Porter hypothesis" based on the perspective of green technology innovation. J. Southwest Univ. Political Sci. Law 2020, 2, 125-139.

35. Liu, H.; Yüksel, S.; Dinçer, H. Analyzing the criteria of efficient carbon capture and separation technologies for sustainable clean energy usage. Energies 2020, 10, 2592. [CrossRef]

36. Xia, H.; Tan, Q.; Bai, J. Business environment, enterprise rent-seeking and market innovation: Evidence from the China enterprise survey. Econ. Res. J. 2019, 4, 84-98.

37. Hulten, C.R.; Bennathan, E.; Srinivasan, S. Infrastructure, externalities, and economic development: A study of the Indian manufacturing industry. World Bank Econ. Rev. 2006, 2, 291-308. [CrossRef]

38. Tao, C.; Zhou, X. A study of the threshold effects of environmental regulation, element agglomeration and total factor productivity. Contemp. Financ. Econ. 2015, 1, 10-22.

39. Zhang, C.; Lu, Y.; Guo, L.; Yu, T. The intensity of environmental regulation and technological progress of production. Econ. Res. J. 2011, 2, 113-124.

40. Tong, J.; Liu, W.; Xue, J. Environmental regulation, factor input structure and industrial transformation. Econ. Res. J. 2016, 7, 43-57.

41. Wang, J.; Yang, L. Innovation elements, allocation efficiency and the performance of innovation in the Yangtze river delta region. Shanghai J. Econ. 2020, 1, 75-85.

42. Peng, Y.; Chen, Z.; Lee, J. Dynamic convergence of green total factor productivity in Chinese cities. Sustainability 2020, $12,4883$. [CrossRef]

43. Dong, Z.; Wang, H. Local-neighborhood effect of green technology of environmental regulation. China Ind. Econ. 2019, 1, 100-118.

44. Zhou, M.; Li, Z. Research on innovative capacity of High-tech industry among provinces in China: Based on the view point of industry agglomeration. Sci. Res. Manag. 2011, 1, 15-21.

45. Baron, R.M.; Kenny, D.A. The moderator-mediator variable distinction in social psychological research: Conceptual, strategic, and statistical considerations. J. Personal. Soc. Psychol. 1986, 6, 1173-1182. [CrossRef]

46. Wen, Z.; Marsh, H.W.; Hau, K.T. Structural equation models of latent interactions: An appropriate standardized solution and its scale-free properties. Struct. Equ. Modeling 2010, 17, 1-22. [CrossRef]

47. Richard, F.J.; Haans, R.; Pieters, C.; He, Z.L. Thinking about U: Theorizing and testing U- and inverted U-shaped relationships in strategy research. Strateg. Manag. J. 2016, 37, 1177-1195.

48. Chen, C.; Lan, Q.; Gao, M.; Sun, Y. Green total factor productivity growth and its determinants in China's industrial economy. Sustainability 2020, 12, 1052. [CrossRef]

49. Campisi, D.; Mancuso, P.; Mastrodonato, S.L. Productivity dispersion in the Italian knowledge-intensive business services (KIBS) industry: A multilevel analysis. Manag. Decis. 2021. [CrossRef] 